\title{
Evaluation of renal function in patients with human immunodeficiency virus
}

\author{
Avaliação da função renal de pacientes com vírus da imunodeficiência humana
}

Ederson dos Santos Costa $^{1}$, Déborah Éllen Pinheiro Oliveira ${ }^{1}$, Francilene de Sousa Vieira ${ }^{1}$, Gleciane Costa de Sousa ${ }^{1}$, Maria Edileuza Soares Moura ${ }^{1}$

Objective: to evaluate the renal function of patients undergoing antiretroviral therapy. Methods: documentary, analytical and cross-sectional study with 150 Human Immunodeficiency Virus positive patients, using antiretroviral therapy, who had under gone exams of serum creatinine and abnormal urine elements and sediments, the glomerular filtration rate was calculated by the Chronic Kidney Disease Epidemiology Collaboration equation and renal dysfunction was stratified. Results: $11.3 \%$ of the participants presented a glomerular filtration rate of less than $90 \mathrm{ml} / \mathrm{min} / 1.73 \mathrm{~m}^{2}$. Of these, $8.0 \%$ had renal dysfunction stage 2, and $3.3 \%$, in stage 3 . The variables, older age and prolonged exposure to antiretroviral therapy were statistically significant for altering renal function. Conclusion: estimates of glomerular filtration rate by means of the Chronic Kidney Disease Epidemiology Collaboration equation proved to be an effective measure of early detection of renal function impairment in people living with Human Immunodeficiency Virus/Acquired immunodeficiency syndrome in the use of antiretroviral therapy.

Descriptors: Antiretroviral Therapy, Highly Active; HIV Infections; AIDS-Associated Nephropathy.

Objetivo: avaliar a função renal de pacientes em uso de terapia antirretroviral. Métodos: estudo documental, analítico e transversal com 150 pacientes Human Immunodeficiency Virus positivos, em uso de terapia antirretroviral, aos quais se ofertaram exames de creatinina sérica e de elementos e sedimentos anormais da urina, calculou-se a taxa de filtração glomerular estimada pela equação Chronic Kidney Disease Epidemiology Collaboration e estratificou-se a disfunção renal. Resultados: 11,3\% dos participantes apresentaram taxa de filtração glomerular inferior a $90 \mathrm{ml} / \mathrm{min} / 1,73 \mathrm{~m}^{2}$. Desses, $8,0 \%$ com disfunção renal estágio 2, e 3,3\%, em estágio 3. As variáveis, maior idade e exposição prolongada à terapia antirretroviral, apresentaram significância estatística para alteração da função renal. Conclusão: estimativas da taxa de filtração glomerular por meio da equação Chronic Kidney Disease Epidemiology Collaboration mostrou-se medida efetiva de detecção precoce de alteração da função renal em pessoas vivendo com Human immunodeficiency virus/Acquired immunodeficiency syndrome em uso de terapia antirretroviral.

Descritores: Terapia Antirretroviral de Alta Atividade; Infecções por HIV; Nefropatia Associada a AIDS.

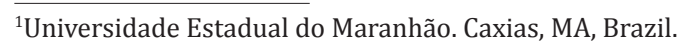




\section{Introduction}

Since the registration of the first cases of Acquired Immunodeficiency Syndrome in Brazil until June $2015,798,366$ cases of this syndrome were reported in the country, $65.0 \%$ of the cases in men, and $35.0 \%$ in women, with a higher prevalence in the age range of 25 and 39 years, for both sexes ${ }^{(1)}$. Access to highly active antiretroviral therapy has expanded since 1996, and 455,000 people were enrolled in this treatment for Human Immunodeficiency Virus in the year 2015, which provided considerable benefits to people living with HIV/AIDS due to increased survival, decreased hospitalizations, opportunistic complications and mortality associated with HIV/AIDS(2).

However, antiretroviral therapy has been linked to toxic effects on renal cells and the prolonged use of some drugs in HIV-infected patients may lead to the development of renal dysfunction by various mechanisms such as nephrolithiasis, intra tubular drug deposition, crystaluria, hematuria, renal atrophy, acute interstitial nephritis and acute and chronic renal failure $^{(3)}$.

It is estimated that $17.0 \%$ of people living with HIV can have chronic kidney disease, which may be related to longer exposure to treatment with some antiretroviral drugs, advanced infection, high viral load, low CD4 + T lymphocyte count, Vascular diseases, metabolic disorders and black race ${ }^{(4)}$. Patients with declining renal function are more likely to have received antiretroviral therapy than patients with normal renal function ${ }^{(5)}$.

Glomerular filtration rate monitoring is considered the best marker of renal function in healthy or sick individuals, since its reduction precedes the onset of renal failure symptoms, allowing the determination of adequate treatment and avoiding progression to the final stage of renal disease ${ }^{(6)}$. In a recent publication by the Department of Health, the recommendation for the evaluation of renal function encourages the use of formulas based on serum creatinine to estimate the rate of glomerular filtration.
Among the changes in the glomerular filtration rate that may result from HIV infection and / or the use of antiretroviral therapy, the objective was to evaluate the renal function of patients taking antiretroviral therapy, to classify the degree of impairment of renal function in those people and the possible factors associated to changes in the glomerular filtration rate.

\section{Methods}

This is a documentary, analytical and cross-sectional study carried out in a specialized care service, located in the countryside of the state of Maranhão, Brazil, from March 2015 to May 2016.

From a population of 423 patients assisted at the specialized care service, a sample of 150 participants was analyzed. Inclusion criteria were: patients aged 18 years or over, enrolled in the specialized care service, being on antiretroviral therapy for more than six months, without interruptions. Exclusion criteria: patients with chronic kidney disease prior to HIV diagnosis.

Data were collected after signing the informed consent form by the patients, using a questionnaire and a detailed analysis of the medical records, raising data on specific risk factors for the development of chronic kidney disease in people living with HIV/AIDS such as: clinical laboratory data such as viral load, CD4 + T lymphocyte counting, urine summary and health history (hypertension, diabetes mellitus), family history and race, besides other factors considered as general risks, old age, smoking, chronic infection and anthropometric data such as weight $(\mathrm{kg})$ and height $(\mathrm{m})^{(7)}$.

The Nefrocalc 2.0 calculator, available on the website of the Brazilian Society of Nephrology ${ }^{(8)}$, was used to facilitate the estimation of the glomerular filtration rate and the adjustment of drug doses in renal failure, so that from conventional creatinine, the creatinine isotope dilution mass spectrometry (IDMS) could be obtained, the standardization methodology for creatinine measurement with the aim of reducing 
its variability.

Serum creatinine was obtained by the serum creatinine determination system, according to the manufacturer's instructions (Labtest). Examination of abnormal elements and sediment, Uri-Color Check Reagent Tape (WAMA), was performed to detect, especially, the presence of proteins, red blood cells and glucose. The estimated glomerular filtration rate was calculated using the equation Chronic Kidney Disease Epidemiology Collaboration (CKD-EPI). Renal dysfunction was classified into six stages based on glomerular filtration rate, according to consensus on the management of renal disease in HIV-infected patients $^{(9)}$.

The data analysis used the EpiInfo Software (for Windows version 3.5.3/2011), a system of word processing, database and statistical analysis for use in epidemiology, to calculate the prevalence of renal changes and correlated factors. Considering a confidence interval of $95.0 \%$ and a margin of error of 5.0\%, the Fisher-Freeman-Halton test was used to measure the association between the dichotomous variables considered as statistically significant, $p<0,05$.

The study complied with the formal requirements contained in national and international standards for research involving human subjects.

\section{Results}

After analyzing the data, it was identified that $62.7 \%(94 / 150)$ of the patients were aged between 30 and 49 years, predominantly males with $53.3 \%$ (80/150), the most informed schooling was elementary education (1 to 9 years of study) with $68.7 \%$ $(103 / 150)$ and the dark skin color was the most mentioned $67.3 \%$ (101/150).

Hypertensive and diabetic patients are more susceptible to renal impairment. These clinical conditions were reported by $8.0 \%(12 / 150)$ and $2.7 \%$ (4/150), respectively, and 2.0\% (3/150) were aware of these two clinical conditions simultaneously. At least $13.3 \%(20 / 150)$ of the participants reported a family history of renal disease, 16.0\% (24/150) used tobacco, a predisposing factor for the development of cardiovascular diseases and a secondary risk factor for Chronic kidney disease. In the evaluation of body mass index, it was observed that $38.7 \%$ (58/150) were classified as overweight, of these $19.3 \%$ (29) were considered pre-obese, $11.3 \%$ (17/150) overweight, 6 $\%(9 / 150)$ obesity grade 1 and $2 \%(3 / 150)$ obesity grade 2 and only 3.3\% (5/150) were underweight.

High viral load and low CD4 + T lymphocyte count are parameters that are related to altered glomerular filtration, $77.3 \%$ (116/150) had undetected viral load values, i.e., low viral load per milliliter of blood, 13.3\% (20/150) with values between 40 and 9,999 copies $/ \mathrm{ml}$ and the others, values above this. The prevalence of CD4 + T lymphocyte count was greater than 200 cells/ $\mu$ l in $79.3 \%$ (119/150) of the participants. Laboratory data on viral load and CD4 + T lymphocyte counts were not considered statistically significant for renal dysfunction among patients enrolled in this analysis, and may be related to maintenance of renal function.

The classification of the estimated glomerular filtration rate was stratified, so that of the participants who presented a result lower than $90 \mathrm{ml} / \mathrm{min} / 1.73 \mathrm{~m}^{2}$ (11.3\%; 17), 8.0\% were classified in grade 2 and 3.3 $\%$ in grade 3 , (Table 1 ). Among the participants, there was no estimated glomerular filtration rate below $30 \mathrm{ml} / \mathrm{min} / 1.73 \mathrm{~m}^{2}$.

Table 1 - Rate of Estimated Glomerular Filtration of patients under antirretroviral therapy registered in the Service of Specialized Care

\begin{tabular}{|c|c|c|c|}
\hline Stages & $\begin{array}{c}\text { GFR }(\mathrm{ml} / \\
\left.\min / 1.73 \mathrm{~m}^{2}\right)\end{array}$ & n (\%) & CR 95\% \\
\hline 1 - Normal or high & $\geq 90$ & $133(88.7)$ & $83.6-93.8$ \\
\hline 2 - Slight decrease & $60-89$ & $12(8.0)$ & $3.7-12.3$ \\
\hline $\begin{array}{l}\text { 3a - Slight and moderate } \\
\text { decrease }\end{array}$ & $45-59$ & $4(2.6)$ & $0.1-5.1$ \\
\hline $\begin{array}{l}\text { 3b - Moderate and severe } \\
\text { decrease }\end{array}$ & $30-44$ & $1(0.7)$ & $-0.6-2.0$ \\
\hline 4 - Serious decrease & $15-29$ & -- & -- \\
\hline 5 - Renal failure & $<15$ & -- & -- \\
\hline
\end{tabular}


Age was a variable that presented statistical significance $(\mathrm{p}=0.001)$ for the change in renal function in people who acquired HIV/AIDS, demonstrating that the older the person, the more susceptible he will be to have renal dysfunction. Although there was a predominance of males, there was a greater aggregation of renal dysfunction with females, as well as dark skin color, however, with no statistically significant value ( $p>0.05$ ). Although it did not reach a significant value, $88.2 \% 15 / 17$ ) of subjects with less than five years of schooling had altered renal function ( $\mathrm{p}=0.067)$, according to (Table 2).

Table 2 - Social demographic aspects and glomerular filtration rate of patients assisted at the Service of Specialized Care

\begin{tabular}{|c|c|c|c|c|}
\hline \multirow[b]{2}{*}{ Variables } & \multicolumn{3}{|c|}{ Glomerular Filtration Rate } & \multirow[b]{2}{*}{$\mathbf{p}$} \\
\hline & $\begin{array}{c}30 \text { to } 59 \\
\text { n (\%) }\end{array}$ & $\begin{array}{c}60 \text { to } 89 \\
\text { n (\%) }\end{array}$ & $\begin{array}{c}\geq 90 \\
\text { n (\%) }\end{array}$ & \\
\hline Gender & & & & $0.339 *$ \\
\hline Male & $1(20.0)$ & $6(50.0)$ & $73(54.9)$ & \\
\hline Female & $4(80.0)$ & $6(50.0)$ & $60(45.1)$ & \\
\hline Age (years) & & & & $0.001^{*}$ \\
\hline 18 to 29 & - & $1(8.3)$ & $16(12.0)$ & \\
\hline 30 to 39 & $1(20.0)$ & - & 47 (35.3) & \\
\hline 40 to 49 & - & $6(50.0)$ & $40(30.1)$ & \\
\hline 50 to 59 & $2(40.0)$ & $2(16.7)$ & $24(18.0)$ & \\
\hline$>60$ & $2(40.0)$ & $3(25.0)$ & $6(4.5)$ & \\
\hline Color & & & & $0.522^{*}$ \\
\hline White & - & $1(8.3)$ & $16(12.0)$ & \\
\hline Dark Skin & $4(80.0)$ & $10(83.3)$ & $87(65.4)$ & \\
\hline Yellow & - & $1(8.3)$ & $5(3.8)$ & \\
\hline Black & $1(20.0)$ & - & $16(12.0)$ & \\
\hline Schooling & & & & $0.067^{*}$ \\
\hline No schooling & $1(20.0)$ & $3(25.0)$ & 19 (14.3) & \\
\hline $1^{\text {st }}$ to $4^{\text {th }}$ grade & $4(80.0)$ & $7(58.3)$ & $38(28.6)$ & \\
\hline $5^{\text {th }}$ to $9^{\text {th }}$ grade & - & $2(16.7)$ & $52(39.1)$ & \\
\hline High school & - & - & 21 (15.8) & \\
\hline University & - & - & $3(2.3)$ & \\
\hline
\end{tabular}

In the study of abnormal urine elements and sediments, $2.0 \%(3 / 150)$ of the participants presented hematuria and $1.3 \%(2 / 150)$ presented glycosuria and proteinuria, each. The creatinine values were converted to IDMS creatinine using the Nefrocalc 2.0
Software to obtain the estimated glomerular filtration rate. Thus, from the corrected data, 36.7\% (55/150) of the participants presented a creatinine value IDMS $=0.5,29.4 \%(44 / 150)$ values between 0.6 and 0.8 and the remaining $16.7 \%(25 / 150)$ with a value equals to or greater than 0.9 .

Regarding treatment time, 46.0\% (69/150) had more than five years of antiretroviral therapy; of these, $15.9 \%(11 / 69)$ had an estimated glomerular filtration rate below $90 \mathrm{ml} / \mathrm{min} / 1.73 \mathrm{~m}^{2}$ which is equivalent to $64.7 \%$ of the total number of patients with altered renal function. The analysis of association time of treatment and renal function showed statistical significance $p=0.033$, prolonged exposure to antiretroviral drugs may be related to renal dysfunction in people living with HIV/AIDS, given the longevity achieved with antiretroviral drugs (Table 3).

Table 3 - Association of treatment time with renal function of patients living with HIV/AIDS registered in the Service of Specialized Care

\begin{tabular}{|c|c|c|c|}
\hline \multirow{2}{*}{ Treatment time (years) } & \multicolumn{2}{|c|}{$\begin{array}{c}\text { Renal Function }(\mathrm{ml} / \\
\left.\min / 1.73 \mathrm{~m}^{2}\right)\end{array}$} & \multirow[t]{2}{*}{$\mathbf{p}$} \\
\hline & n (\%) & n (\%) & \\
\hline$<1$ & $2(1.8)$ & $13(9.8)$ & $0.033^{*}$ \\
\hline 1 to 2 & $1(5.9)$ & $37(27.8)$ & \\
\hline 3 to 4 & $3(17.6)$ & $25(18.8)$ & \\
\hline 5 to 6 & $3(17.6)$ & 27 (20.3) & \\
\hline 7 to 8 & $3(17.6)$ & $19(14.3)$ & \\
\hline 9 to 10 & $1(5.9)$ & $8(6.0)$ & \\
\hline$>10$ & $4(23.5)$ & $4(3.0)$ & \\
\hline
\end{tabular}

The medications used in the treatment of HIV infection prevalent were lamivudine 97.3\% (146/150), efavirenz 72\% (108/150), followed by zidovudine and tenofovir, 60.7\% (91/150), 38.7\% (58/150), respectively. When comparing the glomerular filtration rate, considered to be lower than $90 \mathrm{ml} /$ $\min / 1.73 \mathrm{~m}^{2}$, lamivudine, efavirenz and zidovudine were predominant among the participants, however, there was no statistical significance for altering renal function. 


\section{Discussion}

This study had as limitation the evaluation of the glomerular filtration rate from a single serum creatinine measurement, considering the minimum time of six months for a new evaluation, from this, it is suggested other studies that can perform periodic evaluations and thus analyze the course of evolution of renal filtrate measurement.

In older patients, this evaluation may need other indicators; however, urine sediment screening did not show relevant results in this investigation, so the authors' recommendation is that, given the results, it could be possible to criticize on what we have made evident.

It was found that $11.3 \%$ of the participants in this study had a glomerular filtration rate $<90 \mathrm{ml} /$ $\min / 1.73 \mathrm{~m}$. However, this percentage frequency was lower than that reported in the study carried out on 1970 patients taking antiretroviral drugs, estimated using the CKD-EPI formula, $16.4 \%^{(10)}$. However, it is similar to considering a glomerular filtration rate between 30 and $59 \mathrm{ml} / \mathrm{min} / 1.73 \mathrm{~m}^{2}, 3.1 \%^{(11)}$.

In a study carried out with 254 patients, attended by the simplified Modified Diet in Renal Disease program in the Santa Casa de Vitória, Espirito Santo, Brazil, 9.8\% of these patients had a glomerular filtration rate below $60 \mathrm{ml} / \mathrm{min} / 1.73 \mathrm{~m} 2$ while, using the Crockoft-Gault (CG) formula, they were $6.7 \%^{(12)}$. The divergence of the values found is possibly due to the different methods used and also to the characteristics of each population.

According to a consensus about the management of renal disease in HIV-infected patients, standardization in serum creatinine measurement methods aims to decrease its variability and thus estimate the glomerular filtration rate with greater precision ${ }^{(9)}$. Serum creatinine-based parameters such as age, gender and race have been the best way to assess renal function, with the CKD-EPI equation being the most accurate formula for estimating renal filtration ${ }^{(9,13)}$. It can be used for both pharmaceutical and food indus- tries, as well as recommendations for the dosage of specific antiretroviral drugs based on the categories of renal function ${ }^{(13)}$.

The presence of intermediate risk factors for chronic kidney disease such as hypertension and diabetes mellitus should be continuously monitored, as well as modifiable, smoking and overweight should be corrected for preservation of renal function in people infected with HIV/AIDS, although such factors have not reached statistical significance in the study population, HIV infection and the continuous use of some antiretroviral have been related to an increase in the case of renal dysfunction in this population.

The increase in life expectancy provided by antiretroviral therapy favored the growing number of seropositive cases in the older population, in addition to primary infections at more advanced ages. The advanced age and longer time of exposure to HIV were statistically significant for alteration of the glomerular filtration rate $(\mathrm{p}<0.05)^{(5.14)}$. Diabetes, hypertension, and TCD 4 + lymphocyte count below 200 cells $/ \mathrm{mm}^{2}$ are also associated with renal dysfunction, but without a significant association ${ }^{(14)}$.

The goal of antiretroviral therapy is to suppress viral load and maintain high levels of CD4 $+\mathrm{T}$ lymphocytes. In a cohort of $61 \mathrm{HIV}$ patients treated at a hospital in southern Brazil from 2004 to 2014, who underwent renal biopsy due to renal complications (excluding those undergoing transplantation and/ or dialysis treatment) It was found that the CD4 + T cell count $\geq 200 / \mathrm{mm}^{2}$ compared to those with CD $4+$ $\mathrm{T}$ cells $<200$ cells $/ \mathrm{mm}^{2}$ over an average period of 25 months, renal function remained more preserved, being a protective factor against the terminal renal disease or death ${ }^{(15)}$.

In an observational study, in a center of high complexity in Northern India, with a total of 526 HIV-positive patients, 91 (17.3\%) with renal impairment were found, who considered proteinuria or renal dysfunction and only $28.6 \%$ (26/91) returned to follow-up. Of these, $50.0 \%$ presented only proteinuria ${ }^{(16)}$. In a sample of 538 HIV-infected, untreated patients in 
China, a prevalence of $16.1 \%$ of chronic kidney disease and $12.2 \%$ of proteinuria analyzed by 24 -hour urine were identified ${ }^{(17)}$.

The divergence of proteinuria parameters is probably due to the long follow-up period, which allowed for periodic evaluations, as well as the application of other diagnostic methods in related studies.

When considering the glomerular filtration rate $<60 \mathrm{ml} / \mathrm{min} / 1.73 \mathrm{~m}^{2}$, it was identified that, in addition to other factors, the longer time of HIV infection was associated with altered renal function ${ }^{(14)}$. The aging of people living with HIV/AIDS without the use of antiretroviral therapy has a greater exposure to drug therapy, which makes them more susceptible to the onset of chronic inherited diseases of age, as well as to the cumulative harmful effects of antiretroviral drugs.

The relationship of renal function alteration and antiretroviral therapy has opened many discussions over the years ${ }^{(14,18-19)}$, there was no association between alteration of renal function related to the use of antiretroviral in this investigation.

The persistent suppression of viral load favored by the introduction of new drugs has provided a decrease in renal cholinergic disease and an improvement in renal function, but some anti-retroviral drugs such as tenofovir have been constantly associated with toxic effects and renal alterations ${ }^{(3,15,18)}$, as well as indinavir, cidofovir in events such as tubular damage with clinical picture of Fanconi syndrome, nephrogenic, diabetes insipidus and also renal tubular $\operatorname{acidosis}^{(3)}$.

Combinations of different antiretroviral drugs, both containing tenofovir; tenofovir + atazanavir ritonavir had a significant reduction in the glomerular filtration rate versus the combination of tenofovir + efavirenz over a 48 -week period ${ }^{(19)}$. However, it was not possible to cross the therapeutic schemes in this study due, to the different associations in the analyzed sample.

\section{Conclusion}

However, the estimation of the glomerular filtration rate in HIV/AIDS infected individuals using the CKD-EPI formula has been shown to be an early detection of altered renal function and should be routinely applied in clinical practice in all patients using antiretroviral therapy.

\section{Acknowledgments}

To Fundação de Amparo à Pesquisa e Desenvolvimento Científico do Maranhão (Foundation for Scientific Research and Development of Maranhão), Notice No. 03/2015, for financial support, Process BIC-02358/15.

\section{Collaborations}

Costa ES contributed in designing the project, analyzing and interpreting the data. Oliveira DEP, Vieira FS and Sousa GC contributed in the writing of the article and in the relevant critical revision of the intellectual content. Moura MES contributed in the conception of the project, analysis and interpretation of the data and final approval of the version to be published.

\section{References}

1. Ministério da Saúde (BR). Secretaria de Vigilância em Saúde. Departamento de DST, Aids e Hepatites Virais. Boletim Epidemiológico - Aids e DST. Brasília: Ministério da Saúde; 2015.

2. Ministério da Saúde (BR). Informes do Departamento de DST, Aids e Hepatites Virais. 43를 Reunião da Comissão Nacional de Articulação com Movimentos Sociais em HIV/Aids e Hepatites. Brasília: Ministério da Saúde; 2016.

3. Maggi P, Bartolozzi D, Bonfanti P, Calza L, Cherubini C, Biagio AD, et al. Renal Complications in HIV Disease: between present and future. AIDS Rev. 2012; 14(1):37-53. 
4. Winston JA. HIV and CKD epidemiology. Adv Chronic Kidney Dis. 2010; 17(1):19-25.

5. Tordato F, Lepri AC, Cicconi P, Luca A, Antinori A, Colangeli V, et al. Evaluation of glomerular filtration rate in HIV-1-infected patients before and after combined antiretroviral therapy exposure. HIV Med. 2011; 12(1):4-13.

6. Santos EM, França AKTC, Salgado JVL, Brito DJA, Calado IL, Santos AM, et al. Valor da equação Cockcroft-Gault na triagem de função renal reduzida em pacientes com hipertensão arterial sistêmica. J Bras Nefrol. 2011; 33(3):313-21.

7. Ministério da Saúde (BR). Secretaria de Vigilância em Saúde Departamento de DST, Aids e Hepatites Virais. Protocolo clínico e diretrizes terapêuticas para manejo da infecção pelo HIV em adultos. Brasília: Ministério da Saúde; 2013.

8. Nefrocalc 2.0. Calculadora de filtração glomerular e ajuste de fármacos em insuficiência renal. [Internet]. 2016 [citado 2016 ago 2]. Disponível em: http://www.nefrocalc.net/

9. Gorriz JL, Gutiérrez F, Trullas JC, Arazo P, Arribas JR, Barril G, et al. Consensus document on the management of renal disease in HIV-infected patients. Nefrologia. 2014; 34(Suppl.2):1-81.

10. Reis RK, Santos CB, Dantas RAS, Gir E. Quality of life, sociodemografic factors and sexuality of people living with hiv/aids Texto Contexto Enferm. 2011; 20(3):565-75.

11. Santiago P, Grinsztejn B, Friedman RK, Cunha CB, Coelho LE, Luz PM, et al. Screening for decreased glomerular filtration rate and associated risk factors in a cohort of HIV-infected patients in a middle-income country. Plos One [Internet]. 2014 [cited 2016 July 10]; 4:1-7. Available from: http:// journals.plos.org/plosone/article?id=10.1371/ journal.pone.0093748

12. Pinto Neto LFS, Braga AC, Rocha JÁ, Vieira NFR, Miranda AE. Fatores de risco associados a alterações renais em pacientes infectados por HIV-1. Rev Soc Bras Medicina Tropical. 2011; 44(1):30-4.
13. Okparavero AA, Tighiouart H, Krishnasami Z, Wyatt CM, Graham H, Hellinger J, et al. Use of glomerular filtration rate estimating equations for drug dosing in HIV-positive patients. Antivir Ther. 2013; 18(6):793-802.

14. Crum-Cianflone NF, Ganesan A, Mora NT, Riddle M, Medina S, Barahona I, et al. Prevalence and Factors Associated with Renal Dysfunction Among HIVInfected Patients. AIDS Patient Care STDS. 2010; 24(6):353-60.

15. Silva DR, Gluz IC, Kurz J, Thomé GG, Zancan $\mathrm{R}$, Bringhenti RN, et al. Multiple facets of HIVassociated renal disease. Braz J Med Biol Res [Internet]. 2016 [cited 2016 Sept 19]; 49(4):1-7. Available from: http://www.scielo. br/scielo.php?script=sci_arttext $\&$ pid=S0100879X2016000400709

16. Gupta V, Gupta S, Sinha S, Sharma SK, Dinda AK, Agarwal SK, et al. HIV associated renal disease: A pilot study from north India. Indian J Med Res. 2013; 137(5):950-6.

17. Cao Y, Gong M, Han Y, Xie J, Li X, Zhang L, et al. Prevalence and risk factors for chronic kidney disease among HIV-infected antiretroviral therapy-naïve patients in Mainland China: A multicenter cross-sectional study. Nephrollogy. 2013; 18(4):307-12.

18. Horbert $M$, Tang B, Towner W, Silverberg $M$, Bersoff-Matcha S, Hurley $L$, et al. Impact of tenofovir on renal function in HIV-infected, antiretroviral-naive patients. J Acquir Immune Defic Syndr. 2010; 53(1):62-9.

19. Albini L, Cesana BM, Motta D, Foca E, Gotti D, Calabresi A, et al. A Randomized, pilot trial to evaluate glomerular filtration rate by creatinine or cystatin in naive HIV-infected patients after tenofovir/emtricitabine in combination with atazanavir/ritonavir or efavirenz. J Acquir Immune Defic Syndr. 2012; 59(1):18-30. 